\title{
Current progress in dengue vaccines
}

\author{
Shu-Wen Wan ${ }^{1,2}$, Chiou-Feng Lin ${ }^{1,2,3}$, Shuying Wang ${ }^{1,2}$, Yu-Hung Chen ${ }^{4}$, Trai-Ming Yeh ${ }^{2,5}$, Hsiao-Sheng Liu ${ }^{1,2}$, \\ Robert Anderson ${ }^{1,2,6}$ and Yee-Shin Lin ${ }^{1,2^{*}}$
}

\begin{abstract}
Dengue is one of the most important emerging vector-borne viral diseases. There are four serotypes of dengue viruses (DENV), each of which is capable of causing self-limited dengue fever (DF) or even life-threatening dengue hemorrhagic fever (DHF) and dengue shock syndrome (DSS). The major clinical manifestations of severe DENV disease are vascular leakage, thrombocytopenia, and hemorrhage, yet the detailed mechanisms are not fully resolved. Besides the direct effects of the virus, immunopathological aspects are also involved in the development of dengue symptoms. Although no licensed dengue vaccine is yet available, several vaccine candidates are under development, including live attenuated virus vaccines, live chimeric virus vaccines, inactivated virus vaccines, and live recombinant, DNA and subunit vaccines. The live attenuated virus vaccines and live chimeric virus vaccines are undergoing clinical evaluation. The other vaccine candidates have been evaluated in preclinical animal models or are being prepared for clinical trials. For the safety and efficacy of dengue vaccines, the immunopathogenic complications such as antibody-mediated enhancement and autoimmunity of dengue disease need to be considered.
\end{abstract}

Keywords: Dengue, Immunopathogenesis, Vaccine

\section{Review}

\section{Introduction}

Dengue virus (DENV) is a member of the Flavivirus genus of the Flaviviriade family which also includes yellow fever virus (YFV), West Nile virus (WNV), Japanese encephalitis virus (JEV) and tick-borne encephalitis virus. There are four antigenically distinct serotypes (DENV1-4) based on neutralization assay. DENV is transmitted to humans mainly by Aedes mosquitoes (Aedes aegypti and Aedes albopictus) [1]. The prevalence of dengue disease is high especially in the Asia-Pacific region and the Americas. All four DENV serotypes are now circulating in these areas. With increased international travel and climate change, people are at risk of dengue infection beyond the traditional tropical and subtropical areas. Dengue disease is becoming one of the most important emerging vector-borne viral diseases. An estimated 50 million dengue infection cases

\footnotetext{
* Correspondence: yslin1@mail.ncku.edu.tw

${ }^{1}$ Department of Microbiology and Immunology, National Cheng Kung

University Medical College, Tainan, Taiwan

${ }^{2}$ Center of Infectious Disease and Signaling Research, National Cheng Kung

University, Tainan, Taiwan

Full list of author information is available at the end of the article
}

occur globally with around 500,000 cases of severe dengue and 20,000 deaths per year [2].

\section{Characteristics of dengue virus}

DENV is a lipid-enveloped positive-strand RNA virus. The RNA genome of DENV is about $10.7 \mathrm{~kb}$ and encodes three structural proteins, namely capsid protein $(C)$, precursor membrane/membrane protein (PrM/M), and envelope protein (E). Besides the structural proteins, there are seven nonstructural proteins (NS) which are associated with viral replication and disease pathogenesis. The coding of the viral proteins is organized in the genome as C-prM-E-NS1-NS2A-NS2B-NS3-NS4A-NS4B-NS5 [3,4].

The $C$ protein stabilizes the viral RNA within the viral nucleocapsid. The $\mathrm{N}$-terminus of the $\mathrm{C}$ protein encodes a nuclear localization sequence which allows $\mathrm{C}$ protein translocation into the nucleus and interaction with heterogeneous nuclear ribonucleoprotein [5]. A recent report showed that DENV C protein may interact with human death domain-associated protein Daxx and induce apoptosis [6]. The prM protein acts as a chaperone that helps the folding of $E$ protein. The $M$ protein is a proteolytic fragment derived from its precursor form prM by furin cleavage in the trans-Golgi network. The $\mathrm{E}$

\section{Biomed Central}


protein is the major protein exposed on the virus surface and has three distinct structural domains. Domain I of the $\mathrm{E}$ protein is an eight-stranded $\beta$ barrel and is structurally positioned between domain II and domain III. Domain II contains a dimerization region and a highly conserved fusion loop. Domain III consists of an immunoglobulin-like fold and is the proposed receptor binding domain $[4,7]$.

The NS1 protein is a glycoprotein and is expressed in three forms: an endoplasmic reticulum (ER)-resident form, a membrane-anchored form, and a secreted form. In DENV-infected mammalian cells, NS1 is synthesized as a soluble monomer and is dimerized after posttranslational modification in the ER where it plays an essential role in viral replication (ER-resident form) [8,9]. In infected mammalian cells, secreted NS1 (sNS1) exists as hexamers, and is another dominant target of humoral immunity [10]. Soluble NS1 binds to the plasma membrane of uninfected cells by interactions with heparin sulfate and chondroitin sulfate E [11]. NS1 is expressed on the surface of infected cells as membrane-anchored form, possibly by a glycosylphosphatidyl inositol (GPI) anchor [12] or lipid raft association [13]. The functions of surface expressed NS1 have been reported to include signal transduction [12] and complement activation [11]. In addition, N-linked glycosylation of NS1 modulates its secretion, cell-surface expression, hexamer stability, and interaction with human complement [14].

NS2A can cleave itself from NS1 by its protease activity and at the same time properly processes NS1 in the ER [15]. NS2A is also capable of blocking interferon (IFN)-mediated signal transduction [16]. NS2B is a cofactor of NS3 which together form an active serine protease complex [17]. NS3 is a multifunctional protein with N-terminal protease domain, RNA $5^{\prime}$-triphosphatase, RNA helicase and RNA-stimulated NTPase domain in the $\mathrm{C}$-terminal region. Protease activity is required to process the polyprotein precursor and is essential for viral replication [18]. The helicase activity of NS3 is involved in viral replication and viral assembly $[19,20]$. Both NS4A and NS4B may be involved in blocking IFN- $\alpha / \beta$-induced signal transduction $[16,21]$. However, NS4B can modulate viral replication by its interaction with NS3 [22]. NS5 is the largest and most conserved DENV protein. It encodes two distinct enzyme activities, i.e. $S$-adenosyl methyltransferase which can methylate the 5 'end of viral RNA [23] and RNAdependent RNA polymerase [24].

\section{Dengue disease manifestation and classification}

Infection with DENV may cause mild DF with an onset of fever accompanied by severe headache, retro-orbital pain, myalgia, arthralgia, abdominal pain, rash, and minor hemorrhage in the form of petechiae, epistaxis, or gingival bleeding. Leukopenia and thrombocytopenia may occasionally be observed in DF patients [25]. Severe DHF/DSS generally occurs in those patients who are secondarily infected with a different DENV serotype. However, DHF/DSS may still occur in primary infection [26]. DHF is characterized by all the symptoms of DF but also shows severe bleeding, thrombocytopenia, plasma leakage and organ involvement. Traditionally, there are four grades for classifying DHF. Grades I and II of DHF represent relatively mild cases without shock, whereas grades III and IV of DHF are more severe and might develop to disseminated intravascular coagulation $[27,28]$. The WHO recently reclassified dengue due to difficulties in applying the old classification in the clinical situation $[29,30]$. The new guidelines focus on levels of disease severity and cases are classified as dengue without warning sign, dengue with warning sign, and severe dengue. Patients with severe plasma leakage, severe bleeding or severe organ involvement are defined as severe dengue. The new classification system emphasizes the early recognition of potential manifestations. Therefore, recent reports indicate higher sensitivity using the revised classification [31]. Early prediction is very important to avoid unnecessary hospitalization, especially in hyper-endemic areas. However, whether the new guidelines reduce the specificity of dengue confirmation needs to be further evaluated.

\section{Dengue virus pathogenesis}

The complicated pathogenesis of DHF/DSS is not fully resolved. However, several hypotheses for the pathogenesis of DENV infection have been proposed, including viral pathogenesis and immunopathogenesis, which play significant roles in major manifestations of DHF/DSS, such as hemorrhage, thrombocytopenia, plasma leakage and organ impairment [32-35].

\section{Viral pathogenesis}

Viral pathogenesis indicates the pathology directly caused by the virus which is subject to serotypic or genotypic differences. Differences in transmission efficiency and disease expression between the four serotypes are still uncertain, but DENV-2 and DENV-3 have been associated with an outbreak of severe dengue [36]. Viral genetic and structural differences might contribute to virus variation and influence human disease severity [37-40]. The affinity of DENV for host receptors might affect virus infectivity as well as virulence. Recent studies indicated that certain mutations in the E and NS3 proteins altered the virulence of DENV by enhancing binding activity to host cells and increasing viral replication [41]. 


\section{Immunopathogenesis}

The critical phase of dengue disease is not observed at the peak of viremia but rather when the viral burden has started to decline. This has led to the suggestion that immune responses are not only responsible for virus clearance but also contribute to pathogenesis. The adaptive immune responses, inflammatory mediators and autoimmunity are important factors involved in immunopathogenesis [34,42].

The adaptive immune responses play important roles in the immunopathogenesis of dengue disease. Antibody-dependent enhancement (ADE) is a well-known phenomenon of dengue pathogenesis. From epidemiological studies, the presence of preexisting heterologous antibodies (Abs) which fail to neutralize the current infecting serotype is a major factor for developing DHF/ DSS in both infants and adults [43]. Those subneutralizing Abs enhance viral uptake by $\mathrm{Fc} \gamma$ receptor (Fc $\gamma R$ )-dependent [43] or Fc $\gamma$ R-independent mechanisms [44]. Recently, a new hypothesis (termed intrinsic ADE) postulates that Fc $\mathrm{R}$-mediated DENV internalization suppresses innate immunity, increases interleukin10 production and biases T-helper-1 (Th1) responses to Th2 responses, leading to both high levels of viral load and Abs in dengue patients [45-47]. In addition to neutralizing and infection-enhancing Abs, memory $\mathrm{T}$ cells which cross-react with heterologous viruses could provide partial protective immunity, as well as cause immunopathology [48]. Secondary dengue infections show predominant expansion of $\mathrm{T}$ cells with low affinity for the current infecting serotype and high affinity for the previously infected DENV serotype (known as original antigenic sin) [49]. Numerous studies showed that the cross-reactive $\mathrm{T}$ cells produce high concentrations of inflammatory cytokines which might correlate with plasma leakage in severe dengue [50-53]. DENV-specific human $\mathrm{CD}^{+}{ }^{+}$cytotoxic $\mathrm{T}$ cell clones have been demonstrated to not only produce cytokines but also lyse bystander target cells in vitro [54].

Several studies have shown that patients with severe dengue have elevated plasma markers, such as cytokines, chemokines, soluble receptors, coagulation and endothelial markers [27,55-57]. The abnormal production of plasma markers mainly comes from monocytes [58], T cells [50-53], mast cells [59], and neutrophils [60]. High levels of C3a and C5a have also been measured in dengue patients' plasma [11,61]. In addition, complement could be activated by soluble NS1 and anti-DENV NS1 Abs on DENV-infected endothelial cells [61,62].

Autoantibodies and molecular mimicry represent another contributory factor in dengue disease pathogenesis. Autoantibodies against platelets [63-65], endothelial cells $[66,67]$ and coagulatory molecules [66,68-70] have been observed in dengue patient sera and associated with severe dengue. Molecular mimicry between platelets, endothelial cells or coagulatory molecules with NS1, prM and E proteins may explain the crossreactivity of anti-NS1, anti-prM or anti-E Abs to host proteins. The consequences arising from these crossreactive Abs include platelet dysfunction, endothelial cell apoptosis, coagulation defect, and macrophage activation $[42,57,71,72]$

\section{Protective immune responses}

Both humoral and cellular immunity contribute to DENV clearance and protection. The E protein is the major component on the surface of DENV virion and is a dominant target of $\mathrm{Ab}$ responses against $\mathrm{DENV}$. E protein binds to cellular receptors and mediates fusion between viral envelope and cellular membrane during viral entry [55,73-75]. Passive immunization with anti-E Abs provides protection against DENV infection in mice [76]. Although the NS1 protein is not a component of the virion, the NS1 protein is expressed on the surface of infected cells [12] and is secreted into the circulation [10]. Abs against NS1 can trigger complement-mediated lysis of DENV-infected cells in vitro and protect mice from DENV challenge [77]. In addition, monoclonal Abs against $\mathrm{prM} / \mathrm{M}$ have been shown to provide protection against DENV challenge [78].

Infection with DENV results in the development of $\mathrm{CD}^{+}$and $\mathrm{CD}^{+} \mathrm{T}$ cell responses against multiple viral proteins, of which the NS3 protein appears to be immunodominant [79]. The effector functions of DENVspecific $\mathrm{T}$ cells include cytokine production and target cell lysis [55]. Both DENV-specific $\mathrm{CD}^{+}$and $\mathrm{CD}^{+} \mathrm{T}$ cells protect mice from DENV infection; however $\mathrm{CD}^{+}$ $\mathrm{T}$ cells are more efficient [80-83]. Recent studies further demonstrated that both cross-reactive $\mathrm{B}$ and $\mathrm{T}$ cells provide protection against a secondary heterotypic DENV infection $[84,85]$.

\section{The challenges of dengue vaccine development}

The ideal dengue vaccine should provide long-term homotypic and heterotypic protection. Therefore, there are several factors which require consideration. First, the vaccine must be protective against each of the four DENV serotypes to reduce the risk of ADE. Second, the immunization should be safe and not cause unacceptable side-effects caused by cross-reactive Abs or crossreactive $\mathrm{T}$ cells. Third, the cost should be affordable to the individuals who most need the vaccines [86,87]. There are still several obstacles for the development of dengue vaccines. One is that the complicated pathogenesis is not fully understood. Another hindrance is the lack of suitable animal models. DENV can infect nonhuman primates but does not replicate well or cause marked disease. For reasons of cost and convenience, 
mouse models have been used to test vaccine candidates prior to testing in nonhuman primates. In general, immunocompetent mice are the more suitable models to test the immunogenicity of a vaccine. However, DENV replicates poorly in these mice. Recent progress has been made in modeling dengue in mice, using transgenic, knockout and humanized approaches [88]. One recently described mouse model explored the use of intravenous, intraperitoneal, intracerebal or intradermal inoculation of DENV, resulting in liver pathology, neurological symptoms, thrombocytopenia, or hemorrhage $[89,90]$. In addition, the SCID-tumor mouse model has been tested for live-attenuated dengue vaccine [91] and the immunocompromised mouse model AG129 has been developed for vaccine testing [92].

\section{Current vaccine progress}

Although no licensed dengue vaccine is yet available, several vaccine candidates are under development. These include live attenuated virus vaccines, live chimeric virus vaccines, inactivated virus vaccines, and live recombinant, DNA and subunit vaccines [93]. Live viral vaccines have advanced to clinical trials, but have shown problems, such as unequal immunogenicity of the four serotypes and viral interference among the four serotypes in tetravalent formulations. Non-viral vaccines have also been proposed and developed for safety reasons. This includes subunit vaccines that mostly focused on the $\mathrm{E}$ protein or its derivatives. However, the difficulty of eliciting balanced levels of neutralizing Abs to each of the four serotypes remains a major concern. NS1 is another subunit vaccine candidate that it is not a virionassociated protein and it has no ADE effects [30].

\section{Live attenuated virus vaccines}

Live attenuated virus vaccines contain weakened viruses that still can induce adaptive immune responses to both structural and nonstructural proteins. The replication of live attenuated viruses should be sufficiently restricted to avoid pathological effects. One of the most successful examples of a live attenuated virus vaccine is the 17D strain of YFV, another member of the flavivirus family [94]. Unfortunately the search for an equally successful attenuated dengue vaccine has proven more elusive. In pre-clinical study, live attenuated viruses derived from serially passaged DENV in primary dog kidney (PDK) cells were inoculated in rhesus monkeys to test for viremia and immune responses [95]. Investigators at Mahidol University in Bangkok, Thailand and the Walter Reed Army Research Institute (WRAIR) group in the USA independently developed attenuated DENV vaccine candidates by passage in tissue culture cells for each serotype of DENV [96,97]. Tetravalent dengue vaccine formulations produced by the Mahidol group were used for Phase I and II clinical trials in Thai adults and children. Not all of the volunteers seroconverted to all four DENV serotypes and some showed unacceptable reactogenicity. Consequently, further clinical testing was stopped [98-100]. The WRAIR-produced tetravalent dengue vaccine formulation also showed problems of unbalanced immunogenicity and reactogenicity [97]. New formulations seem to be safe and immunogenic in a Phase II study, however, the protective efficacy needs to be further evaluated [101].

A more modern approach is based on site-directed mutagenesis of the viral genome to cause attenuation. A deletion of 30 nucleotides $(\Delta 30)$ in the 3 '-untranslated region of DENV4 was first demonstrated to attenuate DENV4, named as DEN4 30 [102], and used in Phase I clinical evaluation [103]. However, while this strategy resulted in attenuation for DENV1 and DENV4, with retained immunogenicity, it was less successful for DENV2 and DENV3 [102,104-106]. Hence, an alternative chimeric strategy for DENV2 and DENV3 was designed using the $\triangle 30 D E N 4$ as genetic backbone for DENV2 and DENV3 (designated as DEN2/4 $\Delta 30$ and DEN3/4 $\Delta 30)$. These monovalent DENV vaccines $(\mathrm{DEN} 1 \Delta 30, \mathrm{DEN} 2 / 4 \Delta 30, \mathrm{DEN} 3 / 4 \Delta 30$ and DEN4 $\Delta 30)$ have been tested for attenuation and immunogenicity in animal models and humans, and the attenuated tetravalent DENV vaccine admixtures are currently in Phase I clinical studies [30,107].

\section{Live chimeric virus vaccines}

The most advanced product so far, Sanofi Pasteur's ChimeriVax Dengue tetravalent vaccine (CVD1-4) utilized the licensed YFV 17D vaccine as backbone, each expressing the prM and $\mathrm{E}$ genes of one of the four DENV serotypes. Pre-clinical studies demonstrated that the tetravalent vaccine is genetically and phenotypically stable [108,109], less neurovirulent than YFV 17D [110], and immunogenic in monkeys [111]. In Phase I studies, the tetravalent CVD vaccine appeared safe with relatively low viremia [112-114]. Recently, however, Phase II study showed only 30 percent effectiveness and efficacies against only DENV1, 3 and 4 serotypes [115]. These results indicate that the Sanofi dengue vaccine still carries the risk of $\mathrm{ADE}$ and needs more testing, modification and/or clinical trials especially in dengue-endemic countries [116].

\section{Inactivated virus vaccines}

Inactivated virus vaccines have two advantages over live virus vaccines, i.e. no possibility of reverting to virulence (safety) and relative ease of inducing balanced immune responses (for tetravalent vaccines). However, some challenges remain, such as lack of the immunity to NS proteins and a requirement of adjuvants for enhancing 
immunogenicity. A purified, inactivated DENV2 vaccine has been shown to be immunogenic and protective in mice and rhesus monkeys [117] as well as formulated with adjuvants for inducing higher levels of neutralizing Abs and protection against viraemia [118].

\section{Live recombinant, DNA and subunit vaccines}

Recent advances in molecular biology have spurred dengue vaccine efforts using live recombinant, DNA and subunit vaccines. Generally, the DENV E protein is used as the major immunogen. Certain live viral vectors, such as adenovirus, alphavirus and vaccinia virus are designed for direct administration to the host and have been engineered to express DENV E protein for further evaluation as vaccines [119-121]. In addition, recombinant $\mathrm{E}$ proteins expressed from yeast and insect cells have been used to test for immunogenicity [122-124] and protective efficacy $[124,125]$ in animal models. Truncated $E$ proteins (DEN-8E) produced for all serotypes have been developed with aluminum hydroxide (adjuvant) as tetravalent vaccine formulations [125].

The domain III of the DENV E protein (EDIII) is the proposed receptor binding domain and elicits neutralizing Abs [30]. It has been demonstrated that immunization with recombinant EDIII induces protective Abs against DENV in both mouse [126] and nonhuman primate models [127]. To develop a tetravalent subunit vaccine, Leng et al. have prepared a consensus EDIII (cEDIII) protein by aligning amino acid sequences from different isolates of the four serotypes of DENV. They showed that the novel cEDIII successfully elicited crossneutralizing $\mathrm{Ab}$ responses against four serotypes in a mouse model [128] and neutralizing $A b$ responses against DENV-2 in a nonhuman primate model [129]. An engineered heterologous lipoprotein (recombinant lipo-EDIII) which is EDIII protein fused with lipid signal peptides was reported to induce higher levels of neutralizing Abs than EDIII protein formulated with alum adjuvant [130]. Combining the tetravalent and adjuvant effects, a novel single-dose dengue subunit vaccine (lipocEDIII) was demonstrated to neutralize the four serotypes of DENV and induce memory immune responses [131]. However, recent studies indicated that EDIIIspecific Abs do not constitute a large percentage in the dengue patient sera and only contribute to a small proportion of DENV neutralization in vitro [132-134]. Thus, the main epitope of DENV for neutralizing Abs in the human as well as the applicability of EDIII-based vaccines remain to be defined.

NS1 is not a structural component of the virion, and therefore, does not contribute to ADE. Anti-DENV NS1 Abs are potentially protective antibodies since they trigger complement-mediated lysis of DENV-infected cells [77]. Several studies indicated that passive immunization with anti-NS1 Abs [131], DNA vaccine against NS1 proteins [135-138], or recombinant vaccinia virus expressing NS1 [139] and active immunization with NS1 proteins $[77,140]$ could provide protection in mice against DENV

Table 1 Summary of NS1 subunit vaccine applications in mouse models

\begin{tabular}{|c|c|c|c|c|}
\hline Approach & DENV inoculation & Mouse & Outcome & Reference \\
\hline Monoclonal anti-NS1 Abs & DENV2 (NGC) $100 I C_{50}$ i.c. & $\mathrm{BALB} / \mathrm{C}$ & 50-93\% Survival & {$[135]$} \\
\hline DNA vaccine: & DENV2 (PL046) & $\mathrm{C} 3 \mathrm{H} / \mathrm{HeN}$ & pD2NS1: 50\% Survival & {$[136]$} \\
\hline pD2NS1 & $10^{7}$ PFU i. p. & & $50 \%$ Morbidity & \\
\hline \multirow[t]{2}{*}{ pD2NS1 + plL12 } & & & pD2NS1 + plL12: 80\% Survival & \\
\hline & & & 20\% Morbidity & \\
\hline \multirow[t]{2}{*}{ DNA vaccine: pcTPANS1 } & DENV2 (NGC) & $\mathrm{BALB} / \mathrm{C}$ & $50 \%$ Survival & {$[137]$} \\
\hline & $4,32 \log _{10}$ PFU i.c. & & & \\
\hline DNA vaccine: pcTPANS1* & DENV2 (NGC) & $\mathrm{BALB} / \mathrm{C}$ & pcTPANS1: 96.7\% Survival & {$[138]$} \\
\hline \multirow[t]{3}{*}{ pcENS1 ${ }^{* *}$} & $4,32 \log _{10} P F U$ i.c. & & 10\%Morbidity & \\
\hline & & & pcEN1: 86.7\% Survival & \\
\hline & & & 27\% Morbidity & \\
\hline Vaccinia Virus: & DENV4 $(\mathrm{H} 241)$ & $\mathrm{BALB} / \mathrm{C}$ & $67 \%$ Survival & {$[139]$} \\
\hline vNS1-15\% NS2a & $100 \mid C_{50}$ i.c. & & & \\
\hline \multirow[t]{2}{*}{ rNS1 + CFA (adjuvant) } & DENV2 (NGC) & $\mathrm{BALB} / \mathrm{C}$ & $88 \%$ Survival & {$[77]$} \\
\hline & Lethal dose i.c. & & 18\% morbidity & \\
\hline \multirow[t]{2}{*}{ rNS1 + LT $T_{G 33 D}$ (adjuvant) } & DENV2 (NGC) & $\mathrm{BALB} / \mathrm{C}$ & $50 \%$ Survival & {$[140]$} \\
\hline & $4,32 \log _{10} P F U$ i.c. & & 80\% Morbidity & \\
\hline
\end{tabular}

*TPA human tissue plasminogen activator, a secretory signal sequence.

**pcENS1: encoding the C-terminal E protein plus the NS1 region.

i.c intracerebal, i.p intraperitoneal. 
challenge (Table 1). However, anti-NS1 Abs still have some pathogenic effects as determined both in vitro and in vivo due to cross-reactivity with host proteins [57,71,141]. A safe dengue NS1-based vaccine would likely require the deletion or modification of crossreactive epitopes. In our studies, we have tested the immunogenicity, pathogenic and protective effects of full-length DENV NS1 and NS1 lacking the C-terminal amino acid residues 271-352 (designated $\Delta \mathrm{C}$ NS1). Results showed that the immunogenicity of $\Delta C$ NS1 was similar to that of full-length DENV NS1 but, most importantly, $\triangle \mathrm{C}$ NS1 did not induce pathogenic effects as assayed by cross-reactivity or bleeding tendency [142] In addition, passive immunization with anti- $\Delta C$ NS1 Abs provides protection against DENV infection in a hemorrhagic mouse model (unpublished data). We are currently evaluating the application of $\Delta \mathrm{C}$ NS1 protein for vaccine development.

Another alternative approach is the production of fusion proteins, such as E-NS1 proteins expressed by $E$ coli [143] and prM-E-NS1 proteins encoded by DNA vaccine [144] which provide protection in mice. However, the cross-protection against other serotypes needs to be further investigated.

\section{Conclusions}

Although no licensed dengue vaccine is yet available, the ever-increasing knowledge of dengue pathogenesis, is providing more insights into improved vaccine design. Important aspects of dengue vaccine development include common features such as immunogenicity, reactogenicity and protective efficacy but also dengueunique features such as the heterotypic nature of the virus, the risk of ADE and cross-reactivity with host proteins. Furthermore, all of these aspects should ideally be tempered with considerations of cost and stability.

\section{Competing interests}

The authors declare that they have no competing interests.

\section{Authors' contributions}

All authors discussed and designed the concept. SWW, CFL, RA and YSL collected information and prepared the manuscript. SWW wrote the manuscript. All authors read and approved the final manuscript.

\section{Acknowledgements}

This work was supported by Grants NSC101-2325-B-006-006, NSC101-2321B-006-002 and NSC101-2321-B-006-031 from the National Science Council, Taiwan, and DOH102-TD-B-111-002 from Multidisciplinary Center of Excellence for Clinical Trial and Research, Department of Health, Taiwan.

\section{Author details}

'Department of Microbiology and Immunology, National Cheng Kung University Medical College, Tainan, Taiwan. ${ }^{2}$ Center of Infectious Disease and Signaling Research, National Cheng Kung University, Tainan, Taiwan. ${ }^{3}$ Institute of Clinical Medicine, National Cheng Kung University Medical College, Tainan, Taiwan. ${ }^{4}$ Department of Biochemistry and Molecular Biology, National Cheng Kung University Medical College, Tainan, Taiwan. ${ }^{5}$ Department of Medical Laboratory Science and Biotechnology, National Cheng Kung University Medical College, Tainan, Taiwan. ${ }^{6}$ Departments of
Microbiology \& Immunology and Pediatrics, and Canadian Center for Vaccinology, Dalhousie University, Halifax, Nova Scotia, Canada.

Received: 26 March 2013 Accepted: 13 May 2013

Published: 13 June 2013

\section{References}

1. Simmons CP, Farrar JJ, Nguyen WV, Wills B: Dengue. N Engl J Med 2012, 366:1423-1432.

2. Guzman MG, Halstead SB, Artsob H, Buchy P, Farrar J, Gubler DJ, Hunsperger E, Kroeger A, Margolis HS, Martinez E, et al: Dengue: a continuing global threat. Nat Rev Microbiol 2010, 8:S7-S16.

3. Henchal EA, Putnak JR: The dengue viruses. Clin Microbiol Rev 1990, 3:376-396

4. Clyde K, Kyle JL, Harris E: Recent advances in deciphering viral and host determinants of dengue virus replication and pathogenesis. J Virol 2006 80:11418-11431.

5. Chang CJ, Luh HW, Wang SH, Lin HJ, Lee SC, Hu ST: The heterogeneous nuclear ribonucleoprotein $\mathrm{K}$ (hnRNP K) interacts with dengue virus core protein. DNA Cell Biol 2001, 20:569-577.

6. Netsawang J, Noisakran S, Puttikhunt C, Kasinrerk W, Wongwiwat W, Malasit P, Yenchitsomanus PT, Limjindaporn T: Nuclear localization of dengue virus capsid protein is required for DAXX interaction and apoptosis. Virus Res 2009, 147:275-283.

7. Kaufmann B, Rossmann MG: Molecular mechanisms involved in the early steps of flavivirus cell entry. Microbes Infect 2011,13:1-9.

8. Winkler G, Maxwell SE, Ruemmler C, Stollar V: Newly synthesized dengue-2 virus nonstructural protein NS1 is a soluble protein but becomes partially hydrophobic and membrane-associated after dimerization. Virology 1989, 171:302-305.

9. Welsch S, Miller S, Romero-Brey I, Merz A, Bleck CK, Walther P, Fuller SD, Antony C, Krijnse-Locker J, Bartenschlager R: Composition and threedimensional architecture of the dengue virus replication and assembly sites. Cell Host Microbe 2009, 5:365-375.

10. Flamand M, Megret F, Mathieu M, Lepault J, Rey FA, Deubel V: Dengue virus type 1 nonstructural glycoprotein NS1 is secreted from mammalian cells as a soluble hexamer in a glycosylation-dependent fashion. J Virol 1999, 73:6104-6110.

11. Avirutnan P, Punyadee N, Noisakran S, Komoltri C, Thiemmeca S, Auethavornanan K, Jairungsri A, Kanlaya R, Tangthawornchaikul N, Puttikhunt $C$, et al: Vascular leakage in severe dengue virus infections: a potential role for the nonstructural viral protein NS1 and complement. $J$ Infect Dis 2006, 193:1078-1088.

12. Jacobs MG, Robinson PJ, Bletchly C, Mackenzie JM, Young PR: Dengue virus nonstructural protein 1 is expressed in a glycosyl-phosphatidylinositol-linked form that is capable of signal transduction. FASEB J 2000, 14:1603-1610.

13. Noisakran $S$, Dechtawewat $T$, Avirutnan $P$, Kinoshita $T$, Siripanyaphinyo $U$, Puttikhunt C, Kasinrerk W, Malasit P, Sittisombut N: Association of dengue virus NS1 protein with lipid rafts. J Gen Virol 2008, 89:2492-2500.

14. Somnuke P, Hauhart RE, Atkinson JP, Diamond MS, Avirutnan P: N-linked glycosylation of dengue virus NS1 protein modulates secretion, cell-surface expression, hexamer stability, and interactions with human complement. Virology 2011, 413:253-264.

15. Falgout $B$, Chanock R, Lai CJ: Proper processing of dengue virus nonstructural glycoprotein NS1 requires the N-terminal hydrophobic signal sequence and the downstream nonstructural protein NS2a. J Virol 1989, 63:1852-1860

16. Munoz-Jordan JL, Sanchez-Burgos GG, Laurent-Rolle M, Garcia-Sastre A: Inhibition of interferon signaling by dengue virus. Proc Natl Acad Sci USA 2003, 100:14333-14338

17. Niyomrattanakit $P$, Winoyanuwattikun $P$, Chanprapaph $S$, Angsuthanasombat C, Panyim S, Katzenmeier G: Identification of residues in the dengue virus type $2 \mathrm{NS} 2 \mathrm{~B}$ cofactor that are critical for NS3 protease activation. J Virol 2004, 78:13708-13716.

18. Zhang L, Mohan PM, Padmanabhan R: Processing and localization of Dengue virus type 2 polyprotein precursor NS3-NS4A-NS4B-NS5. J Virol 1992, 66:7549-7554.

19. Matusan AE, Pryor MJ, Davidson AD, Wright PJ: Mutagenesis of the Dengue virus type 2 NS3 protein within and outside helicase motifs: effects on enzyme activity and virus replication. J Virol 2001, 75:9633-9643. 
20. Benarroch D, Selisko B, Locatelli GA, Maga G, Romette JL, Canard B: The RNA helicase, nucleotide 5'-triphosphatase, and RNA 5'-triphosphatase activities of Dengue virus protein NS3 are $\mathrm{Mg}^{2+}$-dependent and require a functional Walker B motif in the helicase catalytic core. Virology 2004, 328:208-218.

21. Munoz-Jordan JL, Laurent-Rolle M, Ashour J, Martinez-Sobrido L, Ashok M, Lipkin WI, Garcia-Sastre A: Inhibition of alpha/beta interferon signaling by the NS4B protein of flaviviruses. J Virol 2005, 79:8004-8013.

22. Umareddy I, Chao A, Sampath A, Gu F, Vasudevan SG: Dengue virus NS4B interacts with NS3 and dissociates it from single-stranded RNA. J Gen Virol 2006, 87:2605-2614

23. Egloff MP, Decroly E, Malet H, Selisko B, Benarroch D, Ferron F, Canard B: Structural and functional analysis of methylation and 5'-RNA sequence requirements of short capped RNAs by the methyltransferase domain of dengue virus NS5. J Mol Biol 2007, 372:723-736.

24. Ackermann M, Padmanabhan R: De novo synthesis of RNA by the dengue virus RNA-dependent RNA polymerase exhibits temperature dependence at the initiation but not elongation phase. J Biol Chem 2001, 276:39926-39937.

25. Kittigul L, Pitakarnjanakul P, Sujirarat D, Siripanichgon K: The differences of clinical manifestations and laboratory findings in children and adults with dengue virus infection. J Clin Virol 2007, 39:76-81.

26. Gubler DJ: Dengue and dengue hemorrhagic fever. Clin Microbiol Rev 1998, 11:480-496.

27. Srikiatkhachorn A, Green S: Markers of dengue disease severity. Curr Top Microbiol Immunol 2009, 338:67-82.

28. Martina BE, Koraka P, Osterhaus AD: Dengue virus pathogenesis: an integrated view. Clin Microbiol Rev 2009, 22:564-581.

29. Bandyopadhyay S, Lum LC, Kroeger A: Classifying dengue: a review of the difficulties in using the WHO case classification for dengue haemorrhagic fever. Trop Med Int Health 2006, 11:1238-1255.

30. Murphy BR, Whitehead SS: Immune response to dengue virus and prospects for a vaccine. Annu Rev Immunol 2011, 29:587-619.

31. Barniol J, Gaczkowski R, Barbato EV, da Cunha RV, Salgado D, Martinez E, Segarra CS, Pleites Sandoval EB, Mishra A, Laksono IS, et al: Usefulness and applicability of the revised dengue case classification by disease: multi-centre study in 18 countries. BMC Infect Dis 2011, 11:106.

32. Lei HY, Yeh TM, Liu HS, Lin YS, Chen SH, Liu CC: Immunopathogenesis of dengue virus infection. J Biomed Sci 2001, 8:377-388.

33. Green S, Rothman A: Immunopathological mechanisms in dengue and dengue hemorrhagic fever. Curr Opin Infect Dis 2006, 19:429-436.

34. Whitehorn J, Simmons CP: The pathogenesis of dengue. Vaccine 2011, 29:7221-7228.

35. Yacoub S, Mongkolsapaya J, Screaton G: The pathogenesis of dengue. Curr Opin Infect Dis 2013, 26:284-289.

36. Guzman A, Isturiz RE: Update on the global spread of dengue. Int J Antimicrob Agents 2010, 36(Suppl 1):S40-S42.

37. Pandey BD, Morita K, Hasebe F, Parquet MC, Igarashi A: Molecular evolution, distribution and genetic relationship among the dengue 2 viruses isolated from different clinical severity. Southeast Asian J Trop Med Public Health 2000, 31:266-272.

38. Vaughn DW, Green S, Kalayanarooj S, Innis BL, Nimmannitya S, Suntayakorn S, Endy TP, Raengsakulrach B, Rothman AL, Ennis FA, Nisalak A: Dengue viremia titer, antibody response pattern, and virus serotype correlate with disease severity. J Infect Dis 2000, 181:2-9.

39. Cologna R, Rico-Hesse R: American genotype structures decrease dengue virus output from human monocytes and dendritic cells. J Virol 2003, 77:3929-3938.

40. Leitmeyer KC, Vaughn DW, Watts DM, Salas R, Villalobos I, de C, Ramos C, Rico-Hesse R: Dengue virus structural differences that correlate with pathogenesis. J Virol 1999, 73:4738-4747.

41. de Borba L, Strottmann DM, de Noronha L, Mason PW, Dos Santos CN Synergistic interactions between the NS3(hel) and E proteins contribute to the virulence of dengue virus type 1. PLoS Negl Trop Dis 2012, 6:e1624

42. Perng GC, Lei HY, Lin YS, Chokephaibulkit K: Dengue vaccines: challenge and confrontation. World J of Vaccines 2011, 1:109-130.

43. Halstead SB: Neutralization and antibody-dependent enhancement of dengue viruses. Adv Virus Res 2003, 60:421-467.

44. Huang KJ, Yang YC, Lin YS, Huang JH, Liu HS, Yeh TM, Chen SH, Liu CC, Lei $H Y$ : The dual-specific binding of dengue virus and target cells for the antibody-dependent enhancement of dengue virus infection. J Immunol 2006, 176:2825-2832.
45. Ubol S, Phuklia W, Kalayanarooj S, Modhiran N: Mechanisms of immune evasion induced by a complex of dengue virus and preexisting enhancing antibodies. J Infect Dis 2010, 201:923-935.

46. Ubol S, Halstead SB: How innate immune mechanisms contribute to antibodyenhanced viral infections. Clin Vaccine Immunol 2010, 17:1829-1835.

47. Halstead SB, Mahalingam S, Marovich MA, Ubol S, Mosser DM: Intrinsic antibody-dependent enhancement of microbial infection in macrophages: disease regulation by immune complexes. Lancet Infect Dis 2010, 10:712-722.

48. Selin LK, Varga SM, Wong IC, Welsh RM: Protective heterologous antiviral immunity and enhanced immunopathogenesis mediated by memory $\mathrm{T}$ cell populations. J Exp Med 1998, 188:1705-1715.

49. Mongkolsapaya J, Dejnirattisai W, Xu XN, Vasanawathana S, Tangthawornchaikul N, Chairunsri A, Sawasdivorn S, Duangchinda T, Dong T, Rowland-Jones S, Yenchitsomanus PT, McMichael A, Malasit P, Screaton G: Original antigenic sin and apoptosis in the pathogenesis of dengue hemorrhagic fever. Nat Med 2003, 9:921-927.

50. Kurane I, Innis BL, Nimmannitya S, Nisalak A, Meager A, Janus J, Ennis FA: Activation of T lymphocytes in dengue virus infections. High levels of soluble interleukin 2 receptor, soluble CD4, soluble CD8, interleukin 2, and interferon-gamma in sera of children with dengue. J Clin Invest 1991, 88:1473-1480.

51. Mangada MM, Rothman AL: Altered cytokine responses of denguespecific $\mathrm{CD}^{+}{ }^{+} \mathrm{T}$ cells to heterologous serotypes. J Immunol 2005 175:2676-2683.

52. Hatch S, Endy TP, Thomas S, Mathew A, Potts J, Pazoles P, Libraty DH, Gibbons R, Rothman AL: Intracellular cytokine production by dengue virus-specific T cells correlates with subclinical secondary infection. $J$ Infect Dis 2011, 203:1282-1291.

53. Malavige GN, Huang LC, Salimi M, Gomes L, Jayaratne SD, Ogg GS: Cellular and cytokine correlates of severe dengue infection. PLOS One 2012, 7:e50387.

54. Gagnon SJ, Ennis FA, Rothman AL: Bystander target cell lysis and cytokine production by dengue virus-specific human CD4(+) cytotoxic Tlymphocyte clones. J Virol 1999, 73:3623-3629.

55. Rothman AL: Immunity to dengue virus: a tale of original antigenic sin and tropical cytokine storms. Nat Rev Immunol 2011, 11:532-543.

56. Espada-Murao LA, Morita K: Dengue and soluble mediators of the innate immune system. Trop Med Health 2011, 39:53-62.

57. Wan SW, Lin CF, Yeh TM, Liu CC, Liu HS, Wang S, Ling P, Anderson R, Lei HY, Lin YS: Autoimmunity in dengue pathogenesis. J Formos Med Assoc 2013, 112:3-11.

58. Anderson R, Wang S, Osiowy C, Issekutz AC: Activation of endothelial cells via antibody-enhanced dengue virus infection of peripheral blood monocytes. J Virol 1997, 71:4226-4232.

59. King CA, Anderson R, Marshall JS: Dengue virus selectively induces human mast cell chemokine production. J Virol 2002, 76:8408-8419.

60. Juffrie M, van Der Meer GM, Hack CE, Haasnoot K, Sutaryo J, Veerman AJ, Thijs LG: Inflammatory mediators in dengue virus infection in children: interleukin-8 and its relationship to neutrophil degranulation. Infect Immun 2000, 68:702-707.

61. Nascimento EJ, Silva AM, Cordeiro MT, Brito CA, Gil LH, Braga-Neto U, Marques ET: Alternative complement pathway deregulation is correlated with dengue severity. PLoS One 2009, 4:e6782

62. Avirutnan P, Malasit P, Seliger B, Bhakdi S, Husmann M: Dengue virus infection of human endothelial cells leads to chemokine production, complement activation, and apoptosis. J Immunol 1998, 161:6338-6346.

63. Lin CF, Lei HY, Liu CC, Liu HS, Yeh TM, Wang ST, Yang TI, Sheu FC, Kuo CF, Lin YS: Generation of IgM anti-platelet autoantibody in dengue patients. J Med Virol 2001, 63:143-149.

64. Saito M, Oishi K, Inoue S, Dimaano EM, Alera MT, Robles AM, Estrella BD Jr, Kumatori A, Moji K, Alonzo MT, et al: Association of increased plateletassociated immunoglobulins with thrombocytopenia and the severity of disease in secondary dengue virus infections. Clin Exp Immunol 2004, 138:299-303.

65. Oishi K, Inoue S, Cinco MT, Dimaano EM, Alera MT, Alfon JA, Abanes F, Cruz DJ, Matias RR, Matsuura $H$, et al: Correlation between increased plateletassociated IgG and thrombocytopenia in secondary dengue virus infections. J Med Virol 2003, 71:259-264.

66. Falconar AK: The dengue virus nonstructural-1 protein (NS1) generates antibodies to common epitopes on human blood clotting, integrin/ 
adhesin proteins and binds to human endothelial cells: potential implications in haemorrhagic fever pathogenesis. Arch Virol 1997, 142:897-916.

67. Lin CF, Lei HY, Shiau AL, Liu CC, Liu HS, Yeh TM, Chen SH, Lin YS: Antibodies from dengue patient sera cross-react with endothelial cells and induce damage. J Med Virol 2003, 69:82-90.

68. Falconar AK: Antibody responses are generated to immunodominant ELK/KLE-type motifs on the nonstructural-1 glycoprotein during live dengue virus infections in mice and humans: implications for diagnosis, pathogenesis, and vaccine design. Clin Vaccine Immunol 2007, 14:493-504.

69. Markoff $L$, Innis BL, Houghten R, Henchal LS: Development of crossreactive antibodies to plasminogen during the immune response to dengue virus infection. J Infect Dis 1991, 164:294-301.

70. Chungue E, Poli L, Roche C, Gestas P, Glaziou P, Markoff LJ: Correlation between detection of plasminogen cross-reactive antibodies and hemorrhage in dengue virus infection. J Infect Dis 1994, 170:1304-1307.

71. Lin YS, Yeh TM, Lin CF, Wan SW, Chuang YC, Hsu TK, Liu HS, Liu CC, Anderson R, Lei HY: Molecular mimicry between virus and host and its implications for dengue disease pathogenesis. Exp Biol Med (Maywood) 2011, 236:515-523.

72. Chuang YC, Lin YS, Liu CC, Liu HS, Liao SH, Shi MD, Lei HY, Yeh TM: Factors contributing to the disturbance of coagulation and fibrinolysis in dengue virus infection. J Formos Med Assoc 2013, 112:12-17.

73. Rothman AL: Dengue: defining protective versus pathologic immunity. J Clin Invest 2004, 113:946-951.

74. van der Schaar HM, Wilschut JC, Smit JM: Role of antibodies in controlling dengue virus infection. Immunobiology 2009, 214:613-629.

75. Wahala WM, Silva AM: The human antibody response to dengue virus infection. Viruses 2011, 3:2374-2395.

76. Kaufman BM, Summers PL, Dubois DR, Eckels KH: Monoclonal antibodies against dengue 2 virus E-glycoprotein protect mice against lethal dengue infection. Am J Trop Med Hyg 1987, 36:427-434.

77. Schlesinger JJ, Brandriss MW, Walsh EE: Protection of mice against dengue 2 virus encephalitis by immunization with the dengue 2 virus nonstructural glycoprotein NS1. J Gen Virol 1987, 68(Pt 3):853-857.

78. Kaufman BM, Summers PL, Dubois DR, Cohen WH, Gentry MK, Timchak RL, Burke DS, Eckels $\mathrm{KH}$ : Monoclonal antibodies for dengue virus prM glycoprotein protect mice against lethal dengue infection. Am J Trop Med Hyg 1989, 41:576-580.

79. Duangchinda T, Dejnirattisai W, Vasanawathana S, Limpitikul W, Tangthawornchaikul N, Malasit P, Mongkolsapaya J, Screaton G: Immunodominant T-cell responses to dengue virus NS3 are associated with DHF. Proc Natl Acad Sci U S A 2010, 107:16922-16927.

80. An J, Zhou DS, Zhang JL, Morida H, Wang JL, Yasui K: Dengue-specific CD8 ${ }^{+} \mathrm{T}$ cells have both protective and pathogenic roles in dengue virus infection. Immunol Lett 2004, 95:167-174.

81. Yauch LE, Zellweger RM, Kotturi MF, Qutubuddin A, Sidney J, Peters B, Prestwood TR, Sette A, Shresta S: A protective role for dengue virusspecific CD8 ${ }^{+}$T cells. J Immunol 2009, 182:4865-4873.

82. Gil L, Lopez C, Lazo L, Valdes I, Marcos E, Alonso R, Gambe A, Martin J, Romero Y, Guzman MG, et al: Recombinant nucleocapsid-like particles from dengue- 2 virus induce protective $\mathrm{CD} 4^{+}$and $\mathrm{CD} 8^{+}$cells against viral encephalitis in mice. Int Immunol 2009, 21:1175-1183.

83. Gil L, Lopez C, Blanco A, Lazo L, Martin J, Valdes I, Romero Y, Figueroa Y, Guillen G, Hermida L: The cellular immune response plays an important role in protecting against dengue virus in the mouse encephalitis model. Viral Immunol 2009, 22:23-30.

84. Zompi S, Santich BH, Beatty PR, Harris E: Protection from secondary dengue virus infection in a mouse model reveals the role of serotype cross-reactive B and T cells. J Immunol 2012, 188:404-416.

85. Zompi S, Montoya M, Pohl MO, Balmaseda A, Harris E: Dominant crossreactive $B$ cell response during secondary acute dengue virus infection in humans. PLoS Negl Trop Dis 2012, 6:e1568.

86. Whitehead SS, Blaney JE, Durbin AP, Murphy BR: Prospects for a dengue virus vaccine. Nat Rev Microbiol 2007, 5:518-528

87. Thomas SJ, Endy TP: Critical issues in dengue vaccine development. Curr Opin Infect Dis 2011, 24:442-450.

88. Cassetti MC, Durbin A, Harris E, Rico-Hesse R, Roehrig J, Rothman A, Whitehead S, Natarajan R, Laughlin C: Report of an NIAID workshop on dengue animal models. Vaccine 2010, 28:4229-4234.
89. Yauch LE, Shresta S: Mouse models of dengue virus infection and disease. Antiviral Res 2008, 80:87-93.

90. Zompi S, Harris E: Animal models of dengue virus infection. Viruses 2012, 4:62-82.

91. Blaney JE Jr, Sathe NS, Hanson CT, Firestone CY, Murphy BR, Whitehead SS: Vaccine candidates for dengue virus type 1 (DEN1) generated by replacement of the structural genes of rDEN4 and rDEN4Delta30 with those of DEN1. Virol J 2007, 4:23.

92. Brewoo JN, Kinney RM, Powell TD, Arguello JJ, Silengo SJ, Partidos CD, Huang CY, Stinchcomb DT, Osorio JE: Immunogenicity and efficacy of chimeric dengue vaccine (DENVax) formulations in interferon-deficient AG129 mice. Vaccine 2012, 30:1513-1520.

93. Murrell S, Wu SC, Butler M: Review of dengue virus and the development of a vaccine. Biotechnol Adv 2011, 29:239-247.

94. Monath TP: Treatment of yellow fever. Antiviral Res 2008, 78:116-124.

95. Eckels KH, Dubois DR, Putnak R, Vaughn DW, Innis BL, Henchal EA, Hoke CH $\mathrm{Jr}$ : Modification of dengue virus strains by passage in primary dog kidney cells: preparation of candidate vaccines and immunization of monkeys. Am J Trop Med Hyg 2003, 69:12-16.

96. Bhamarapravati $\mathrm{N}$, Sutee $\mathrm{Y}$ : Live attenuated tetravalent dengue vaccine. Vaccine 2000, 18(Suppl 2):44-47.

97. Sun W, Edelman R, Kanesa-Thasan N, Eckels KH, Putnak JR, King AD, Houng $H S$, Tang D, Scherer JM, Hoke CH Jr, Innis BL: Vaccination of human volunteers with monovalent and tetravalent live-attenuated dengue vaccine candidates. Am J Trop Med Hyg 2003, 69:24-31.

98. Sabchareon A, Lang J, Chanthavanich P, Yoksan S, Forrat R, Attanath P, Sirivichayakul C, Pengsaa K, Pojjaroen-Anant C, Chokejindachai W, et al: Safety and immunogenicity of tetravalent live-attenuated dengue vaccines in Thai adult volunteers: role of serotype concentration, ratio, and multiple doses. Am J Trop Med Hyg 2002, 66:264-272.

99. Sabchareon A, Lang J, Chanthavanich P, Yoksan S, Forrat R, Attanath P, Sirivichayakul C, Pengsaa K, Pojjaroen-Anant C, Chambonneau L, et al: Safety and immunogenicity of a three dose regimen of two tetravalent live-attenuated dengue vaccines in five- to twelve-year-old Thai children. Pediatr Infect Dis J 2004, 23:99-109.

100. Sanchez V, Gimenez S, Tomlinson B, Chan PK, Thomas GN, Forrat R, Chambonneau L, Deauvieau F, Lang J, Guy B: Innate and adaptive cellular immunity in flavivirus-naive human recipients of a live-attenuated dengue serotype 3 vaccine produced in Vero cells (VDV3). Vaccine 2006, 24:4914-4926.

101. Thomas SJ, Eckels KH, Carletti I, De La Barrera R, Dessy F, Fernandez S, Putnak R, Toussaint JF, Sun W, Bauer K, et al: A phase II, randomized, safety and immunogenicity study of a re-derived, live-attenuated dengue virus vaccine in healthy adults. Am J Trop Med Hyg 2013, 88:73-88.

102. Men R, Bray M, Clark D, Chanock RM, Lai CJ: Dengue type 4 virus mutants containing deletions in the $3^{\prime}$ noncoding region of the RNA genome: analysis of growth restriction in cell culture and altered viremia pattern and immunogenicity in rhesus monkeys. J Virol 1996, 70:3930-3937.

103. McArthur JH, Durbin AP, Marron JA, Wanionek KA, Thumar B, Pierro DJ, Schmidt AC, Blaney JE Jr, Murphy BR, Whitehead SS: Phase I clinical evaluation of rDEN4Delta30-200,201: a live attenuated dengue 4 vaccine candidate designed for decreased hepatotoxicity. Am J Trop Med Hyg 2008, 79:678-684.

104. Whitehead SS, Falgout B, Hanley KA, Blaney JE Jr, Markoff L Jr, Murphy BR: A live, attenuated dengue virus type 1 vaccine candidate with a 30 nucleotide deletion in the $3^{\prime}$ untranslated region is highly attenuated and immunogenic in monkeys. J Virol 2003, 77:1653-1657.

105. Blaney JE Jr, Hanson CT, Hanley KA, Murphy BR, Whitehead SS: Vaccine candidates derived from a novel infectious cDNA clone of an American genotype dengue virus type 2. BMC Infect Dis 2004, 4:39.

106. Blaney JE Jr, Hanson CT, Firestone CY, Hanley KA, Murphy BR, Whitehead SS: Genetically modified, live attenuated dengue virus type 3 vaccine candidates. Am J Trop Med Hyg 2004, 71:811-821.

107. Durbin AP, Kirkpatrick BD, Pierce KK, Schmidt AC, Whitehead SS: Development and clinical evaluation of multiple investigational monovalent DENV vaccines to identify components for inclusion in a live attenuated tetravalent DENV vaccine. Vaccine 2011, 29:7242-7250.

108. Barrett AD, Monath TP, Barban V, Niedrig M, Teuwen DE: 17D yellow fever vaccines: new insights. A report of a workshop held during the World Congress on medicine and health in the tropics, Marseille, France, Monday 12 September 2005. Vaccine 2007, 25:2758-2765. 
109. Barban V, Girerd Y, Aguirre M, Gulia S, Petiard F, Riou P, Barrere B, Lang J: High stability of yellow fever 17D-204 vaccine: a 12-year restrospective analysis of large-scale production. Vaccine 2007, 25:2941-2950.

110. Vlaycheva LA, Chambers TJ: Neuroblastoma cell-adapted yellow fever 17D virus: characterization of a viral variant associated with persistent infection and decreased virus spread. J Virol 2002, 76:6172-6184.

111. Guirakhoo F, Pugachev K, Zhang Z, Myers G, Levenbook I, Draper K, Lang J, Ocran S, Mitchell F, Parsons M, et al: Safety and efficacy of chimeric yellow Fever-dengue virus tetravalent vaccine formulations in nonhuman primates. J Virol 2004, 78:4761-4775.

112. Morrison D, Legg TJ, Billings CW, Forrat R, Yoksan S, Lang J: A novel tetravalent dengue vaccine is well tolerated and immunogenic against all 4 serotypes in flavivirus-naive adults. J Infect Dis 2010, 201:370-377.

113. Poo J, Galan F, Forrat R, Zambrano B, Lang J, Dayan GH: Live-attenuated tetravalent fengue vaccine in dengue-naive children, adolescents, and adults in Mexico City: randomized controlled Phase 1 trial of safety and immunogenicity. Pediatr Infect Dis J 2011, 30:e9-e11.

114. Capeding RZ, Luna IA, Bomasang E, Lupisan S, Lang J, Forrat R, Wartel A, Crevat D: Live-attenuated, tetravalent dengue vaccine in children, adolescents and adults in a dengue endemic country: randomized controlled phase I trial in the Philippines. Vaccine 2011, 29:3863-3872.

115. Sabchareon A, Wallace D, Sirivichayakul C, Limkittikul K, Chanthavanich P, Suvannadabba S, Jiwariyavej V, Dulyachai W, Pengsaa K, Wartel TA, et al: Protective efficacy of the recombinant, live-attenuated, CYD tetravalent dengue vaccine in Thai schoolchildren: a randomised, controlled phase 2b trial. Lancet 2012, 380:1559-1567.

116. Halstead SB: Dengue vaccine development: a 75\% solution? Lancet 2012, 380:1535-1536.

117. Putnak R, Barvir DA, Burrous JM, Dubois DR, D'Andrea VM, Hoke CH, Sadoff $J$ C, Eckels KH: Development of a purified, inactivated, dengue-2 virus vaccine prototype in Vero cells: immunogenicity and protection in mice and rhesus monkeys. J Infect Dis 1996, 174:1176-1184

118. Robert Putnak J, Coller BA, Voss G, Vaughn DW, Clements D, Peters I, Bignami G, Houng HS, Chen RC, Barvir DA, et al: An evaluation of dengue type-2 inactivated, recombinant subunit, and live-attenuated vaccine candidates in the rhesus macaque model. Vaccine 2005, 23:4442-4452.

119. Jaiswal S, Khanna N, Swaminathan S: Replication-defective adenoviral vaccine vector for the induction of immune responses to dengue virus type 2. J Virol 2003, 77:12907-12913.

120. Men R, Wyatt L, Tokimatsu I, Arakaki S, Shameem G, Elkins R, Chanock R, Moss B, Lai CJ: Immunization of rhesus monkeys with a recombinant of modified vaccinia virus Ankara expressing a truncated envelope glycoprotein of dengue type 2 virus induced resistance to dengue type 2 virus challenge. Vaccine 2000, 18:3113-3122.

121. Konishi E, Fujii A: Dengue type 2 virus subviral extracellular particles produced by a stably transfected mammalian cell line and their evaluation for a subunit vaccine. Vaccine 2002, 20:1058-1067.

122. Guzman MG, Rodriguez R, Hermida L, Alvarez M, Lazo L, Mune M, Rosario D, Valdes K, Vazquez S, Martinez R, et al: Induction of neutralizing antibodies and partial protection from viral challenge in Macaca fascicularis immunized with recombinant dengue 4 virus envelope glycoprotein expressed in Pichia pastoris. Am J Trop Med Hyg 2003, 69:129-134.

123. Kelly EP, Greene JJ, King AD, Innis BL: Purified dengue 2 virus envelope glycoprotein aggregates produced by baculovirus are immunogenic in mice. Vaccine 2000, 18:2549-2559.

124. Clements DE, Coller BA, Lieberman MM, Ogata S, Wang G, Harada KE, Putnak JR, Ivy JM, McDonell M, Bignami GS, et al: Development of a recombinant tetravalent dengue virus vaccine: immunogenicity and efficacy studies in mice and monkeys. Vaccine 2010, 28:2705-2715.

125. Coller BA, Clements DE, Bett AJ, Sagar SL, Ter Meulen JH: The development of recombinant subunit envelope-based vaccines to protect against dengue virus induced disease. Vaccine 2011, 29:7267-7275.

126. Chin JF, Chu JJ, Ng ML: The envelope glycoprotein domain III of dengue virus serotypes 1 and 2 inhibit virus entry. Microbes Infect 2007, 9:1-6.

127. Hermida L, Bernardo L, Martin J, Alvarez M, Prado I, Lopez C, Sierra Bde L, Martinez $R$, Rodriguez $R$, Zulueta $A$, et al: A recombinant fusion protein containing the domain III of the dengue- 2 envelope protein is immunogenic and protective in nonhuman primates. Vaccine 2006 , 24:3165-3171.

128. Leng CH, Liu SJ, Tsai JP, Li YS, Chen MY, Liu HH, Lien SP, Yueh A, Hsiao KN, Lai LW, et al: A novel dengue vaccine candidate that induces cross- neutralizing antibodies and memory immunity. Microbes Infect 2009, 11:288-295.

129. Chen HW, Liu SJ, Li YS, Liu HH, Tsai JP, Chiang CY, Chen MY, Hwang CS, Huang CC, Hu HM, et al: A consensus envelope protein domain III can induce neutralizing antibody responses against serotype 2 of dengue virus in non-human primates. Arch Virol 2013. Epub ahead of print PubMed PMID: 23456422

130. Chen HW, Liu SJ, Liu HH, Kwok Y, Lin CL, Lin LH, Chen MY, Tsai JP, Chang LS, Chiu FF, et al: A novel technology for the production of a heterologous lipoprotein immunogen in high yield has implications for the field of vaccine design. Vaccine 2009, 27:1400-1409.

131. Chiang CY, Liu SJ, Tsai JP, Li YS, Chen MY, Liu HH, Chong P, Leng CH, Chen $H W$ : A novel single-dose dengue subunit vaccine induces memory immune responses. PLoS One 2011, 6:e23319.

132. Wahala WM, Kraus AA, Haymore LB, Accavitti-Loper MA, de Silva AM: Dengue virus neutralization by human immune sera: Role of envelope protein domain III-reactive antibody. Virology 2009, 392:103-113.

133. Midgley CM, Bajwa-Joseph M, Vasanawathana S, Limpitikul W, Wills B, Flanagan A, Waiyaiya E, Tran HB, Cowper AE, Chotiyarnwong P, et al: An in-depth analysis of original antigenic sin in dengue virus infection. $J$ Virol 2011, 85:410-421.

134. Williams KL, Wahala WM, Orozco S, de Silva AM, Harris E: Antibodies targeting dengue virus envelope domain III are not required for serotype-specific protection or prevention of enhancement in vivo. Virology 2012, 429:12-20.

135. Henchal EA, Henchal LS, Schlesinger JJ: Synergistic interactions of anti-NS1 monoclonal antibodies protect passively immunized mice from lethal challenge with dengue 2 virus. J Gen Virol 1988, 69(Pt 8):2101-2107.

136. Wu SF, Liao CL, Lin YL, Yeh CT, Chen LK, Huang YF, Chou HY, Huang JL, Shaio MF, Sytwu HK: Evaluation of protective efficacy and immune mechanisms of using a non-structural protein NS1 in DNA vaccine against dengue 2 virus in mice. Vaccine 2003, 21:3919-3929.

137. Costa SM, Freire MS, Alves AM: DNA vaccine against the non-structural 1 protein (NS1) of dengue 2 virus. Vaccine 2006, 24:4562-4564.

138. Costa SM, Azevedo AS, Paes MV, Sarges FS, Freire MS, Alves AM: DNA vaccines against dengue virus based on the ns1 gene: the influence of different signal sequences on the protein expression and its correlation to the immune response elicited in mice. Virology 2007, 358:413-423.

139. Falgout B, Bray M, Schlesinger JJ, Lai CJ: Immunization of mice with recombinant vaccinia virus expressing authentic dengue virus nonstructural protein NS1 protects against lethal dengue virus encephalitis. J Virol 1990, 64:4356-4363.

140. Amorim JH, Diniz MO, Cariri FA, Rodrigues JF, Bizerra RS, Goncalves AJ, de Barcelos Alves AM, de Souza Ferreira LC: Protective immunity to DENV2 after immunization with a recombinant NS1 protein using a genetically detoxified heat-labile toxin as an adjuvant. Vaccine 2012, 30:837-845.

141. Lin CF, Wan SW, Cheng HJ, Lei HY, Lin YS: Autoimmune pathogenesis in dengue virus infection. Viral Immunol 2006, 19:127-132.

142. Chen MC, Lin CF, Lei HY, Lin SC, Liu HS, Yeh TM, Anderson R, Lin YS: Deletion of the C-terminal region of dengue virus nonstructural protein 1 (NS1) abolishes anti-NS1-mediated platelet dysfunction and bleeding tendency. J Immunol 2009, 183:1797-1803.

143. Srivastava AK, Putnak JR, Warren RL, Hoke CH Jr: Mice immunized with a dengue type 2 virus E and NS1 fusion protein made in Escherichia coli are protected against lethal dengue virus infection. Vaccine 1995, 13:1251-1258.

144. Lu H, Xu XF, Gao N, Fan DY, Wang J, An J: Preliminary evaluation of DNA vaccine candidates encoding dengue- $2 \mathrm{prM} / \mathrm{E}$ and NS1: their immunity and protective efficacy in mice. Mol Immunol 2013, 54:109-114.

doi:10.1186/1423-0127-20-37

Cite this article as: Wan et al:: Current progress in dengue vaccines. Journal of Biomedical Science 2013 20:37. 